\title{
Szubjektív életminőség és érzelmi jóllét Magyarországon a gazdasági válság előtt és azt követően, európai kitekintéssel*
}

\author{
Ivonỵ Évo \\ kutató szociológus, \\ a Budapesti Corvinus Egyetem \\ Szociológia Doktori Iskola \\ doktorjelöltje \\ E-mail: evaivony@gmail.com
}

A szerző tanulmányában - mely egy nagyobb kutatás részét képezi - a gazdasági válság évei alatt a lakosság szubjektív életminőségében bekövetkezett elmozdulásokat vizsgálja, eltérő társadalmi-demográfiai metszetekben. Komparatív leíró elemzés keretében veti össze a válság előtti állapotokat a válságkezelés és a kilábalás éveinek időszakával, a kutatás számára kifejlesztett multidimenzionális szubjektív életminőség indikátor segítségével. Az adatokat az Európai társadalmi felmérés 2006-os 3. és 2012-es 6. hullámai biztosítják, míg a nemzetközi kitekintő elemzés a 2015-ös adatokkal is kiegészül. Az eredmények azt mutatják, hogy a fiatalok, a házasságban vagy élettársi kapcsolatban élők, a magasabb erőforrás-ellátottsággal rendelkező csoportok a társadalmi átlagnál kedvezőbb életminőséget tudtak realizálni a válság éveiben is. Az egyedülállók közül az elváltak és az özvegyek átlagostól kedvezőtlenebb szubjektív életminősége lényegesen nem változott. Azonban az idősek (70 év felettiek), a képzetlenek, a munkanélküliek és a tartós betegek, illetve a nagyon rossz szubjektív egészségi állapotban levők egyéni jólléte messze a legkedvezőtlenebb volt 2012-ben. A nemzetközi adatok a jóllét érzelmi oldalának átlagosan csökkenő tendenciáját mutatják az európai és a magyar lakosság körében.

\section{TÁRGYSZÓ:}

Szubjektív életminőség.

Érzelmi jóllét.

DOI: 10.20311/stat2017.10.hu0997

* A szerző ezúton mond köszönetet Spéder Zsolt és Keller Tamás témavezetöknek, valamint Szabó Laurának és Bartus Tamásnak hasznos észrevételeikért. 
A 2008-as pénzügyi és gazdasági válság Magyarországon is jelentős változásokat eredményezett a gazdasági, a társadalmi és a személyes élet folyamataiban. A krízis kezelését célzó gazdasági és társadalompolitikai intézkedések a lakosságra növekvő anyagi terheket róttak, a napról napra változó intézményi és jogi környezet állandó bizonytalanságérzetet, stresszt és frusztrációt eredményezett mind a gazdasági szereplők, mind a lakosság körében. A válságot követően a magyar társadalom polarizáltsága megerősödött, melynek hátterében a szegénységi és munkaerőpiaci kockázatok növekedése, a szociális transzferek csökkenése, a foglalkoztatás lassú emelkedése és az évröl évre elmaradó bérfelzárkóztatás állt (Szivós-Tóth [2013], Gábos et al. [2014], Scharle [2016]). A recesszió negatív következményei elsősorban a fiatalokat, az alsó jövedelmi csoportokat, az alacsony képzettséggel rendelkezőket és az egyszülős családokat sújtották (Medgyesi-Nagy [2014], Gábos et al. [2016]). A magyar társadalom szubjektív jóllétének időbeli alakulását 2001 és 2015 között az 1. ábra mutatja be. Látható, hogy a lakosság átlagos elégedettsége az élettel, illetve boldogságérzete a válság időszakában jelentősen csökkent, valamint a kilábalás éveit követően 2012-re nem érte el a 2008 előtti szintet. Azonban 2012-től mindkét mutató esetében javulás figyelhető meg.
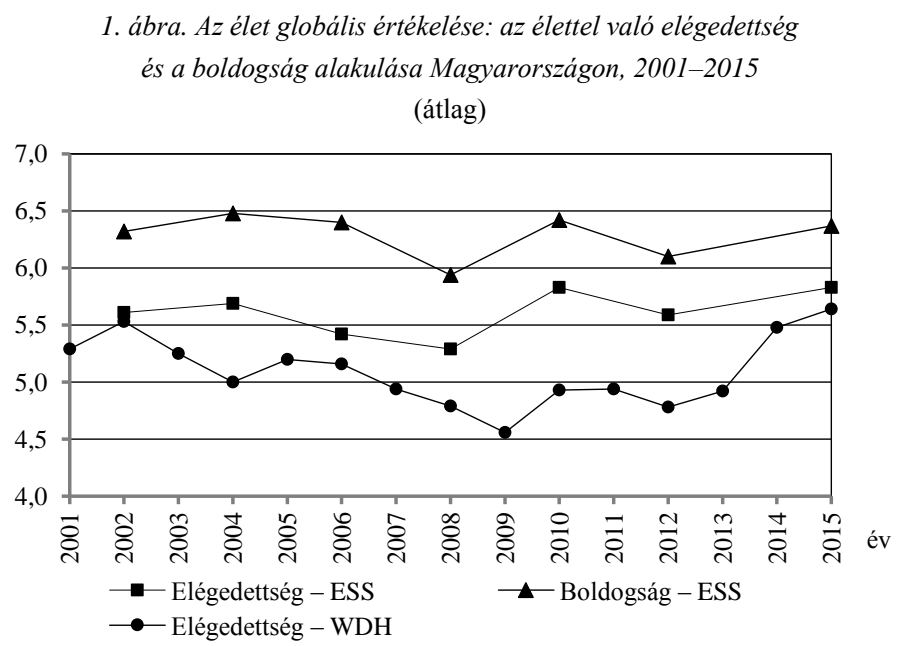

Megjegyzés. ESS (European Social Survey - Európai társadalmi felmérés) adatfelvételének 1-7. hullámai (saját számítás). Az élet racionális és érzelmi értékelését minden hullámban azonos módon kérdezték le: „Mindent összevetve, mennyire elégedett mostani életével?” és „Mindent egybevetve, mennyire érzi magát boldognak?". A válaszokat 0 -tól 10-ig terjedő skálán rögzítették, ahol a 0 a teljesen elégedetlen, nagyon boldogtalan, a 10-es a teljesen elégedett, nagyon boldog értékkategóriát jelentette. WDH (World Database of Happiness - a világ országait átfogó boldogság-adatbázis) (Veenhoven [2016]). 
A válság éveiben a gazdasági folyamatok alakulását mérő makroindikátorok közül néhány mutató (a munkanélküliségi ráta, illetve ezen belül a 15-24 évesek rátája, az inflációs ráta) kedvezőtlenebb értékeket jelzett 2012-ben, mint 2009-ben. Ugyanakkor, a válság kirobbanását követően 2012-ig emelkedett az anyagi deprivációban élők aránya a teljes népességen belül, és évről évre nőtt a jövedelemegyenlőtlenség hazánkban. A társadalom és a gazdaság helyzete 2013-tól kezdődően mutatott javuló tendenciát, a gazdaság stabilizálódott, amit a GDP növekvő volumene, a foglalkoztatotti létszám emelkedése (a közfoglalkoztatás bevezetésének köszönhetöen elsősorban), a csökkenő inflációs és munkanélküliségi ráták, illetve az egyenlötlenségi és deprivációs indikátorok is jeleztek (Szivós-Tóth [2015], Gábos et al. [2016]). Ezért a 2012-es évet a válságkezelés és a kilábalás éveinek kumulatív összhatását megragadó időpontként határoztuk meg a vizsgálatban. A szubjektív indikátorok a válság lecsapódását a 2008-2009-es évekre mutatták, ezt követően a válságkezelés éveiben 2010-ben javulást, majd 2012-re ismét visszaesést mértek. (Lásd az 1. ábrát.) A kilábalás évei alatt az egyéni jóllétben bekövetkezett tendenciaszerü változásokra, illetve arra, hogy mely társadalmi csoportok voltak képesek átlagtól magasabb szubjektív életminőséget realizálni a kilábalás éveiben is, jelen leíró és a későbbiekben publikálásra tervezett többváltozós elemzés keres választ. ${ }^{1} \mathrm{~A}$ tanulmány következő fejezetében néhány általános elméleti megközelítést és kutatási előzményt mutatunk be ${ }^{2}$ majd a kutatás számára kifejlesztett többdimenziós szubjektív életminőséget mérő indikátort határozzuk meg, és a vizsgálat további magyarázóváltozóit specifikáljuk. A leíró elemzés eredményeit két fejezetben foglaljuk össze, első lépésben a többdimenziós indikátor elemeinek (öt fő dimenziójának) jellemzői alapján, majd az eltérő társadalmi-demográfiai csoportok szubjektív életminőségének elemzése során. A cikk egy kitekintő nemzetközi elemzéssel, majd rövid összegzéssel zárul.

\section{Elméletek és kutatási előzmények}

Az életminőség szociológiája két nagy összekapcsolódó kutatási területet fog át, az egyéni életminőségnek (quality of life) és a társadalom minőségének (quality of society) vizsgálatát. Az 1960-as éveket követően a jólét (welfare) mélyrehatóbb vizsgálata iránti társadalompolitikai igény az objektív mutatók mellett a szubjektív indikátorok bevezetését hozta magával. Európában az 1970-es évekre tehető ez a folyamat, amikor a szubjektív értékelésre alkalmas mutatókat bevezették a nyugat-

\footnotetext{
${ }^{1}$ Jelen írás a szerző PhD-kutatásának első szakaszában született empirikus eredményeket prezentálja.

${ }^{2}$ A válság hatásvizsgálatainak szakirodalmát a többváltozós elemzésekkel a későbbiekben mutatjuk be.
} 
európai statisztikai rendszerekbe (Allardt [1973], Zapf [1980]). Később, az európai integrációs folyamatokban a tagállamok az egységes uniós indikátorrendszer kifejlesztésén dolgoztak annak érdekében, hogy a globalizáció problémáinak, a növekvő munkaerö-piaci kockázatoknak, a jóléti transzferek csökkenésének, a közszolgáltatások bizonytalanságának és számos más társadalmi problémának a mérése egységesen lehetővé váljon. Mindez az uniós alapdokumentumokban lefektetett jóléti politikák fő célkitüzései megvalósításának, így az életkörülmények és az életminőség javításának monitorozását, továbbá a beavatkozási lehetőségeknek, új típusú indikátoroknak és társadalompolitikai elemzéseknek a kidolgozását szolgálta (Vogel [1997], Harcsa-Spéder [1999], Zapf [2000], Berger-Schmitt-Noll [2000], Delhey et al. [2002], Noll [2002]). Az európai társadalmi jelzőszámrendszer továbbfejlesztésére tett kísérletek az ezredfordulót követően is folytatódtak. Mérföldkőnek számított a 2009-ben megjelent „Stiglitz-Sen-Fitoussi Report” néven ismertté vált javaslat, melyet azonban a korábbi fejlesztésekben meghatározó szerepet játszó szakértők eltérően értékeltek, tekintettel arra, hogy az életminőséghez kapcsolódó több megközelítést és mutatót figyelmen kívül hagyott a jelentés (Noll [2011]).

$\mathrm{Az}$ indikátorrendszerek fejlesztése mellett a társadalomtudósok eltérő makro- és mikroszintü megközelítéseket dolgoztak ki a társadalom és az egyének életminőségbeli különbségeinek magyarázatára. A korai teóriák között kell említeni Allardt [1973] „having, loving, being” néven ismertté vált jóléti koncepcióját, melyben a jólét anyagi feltételeit és realizációs szintjeit (having), a kapcsolatok mennyiségét és minőségét, a társadalmi integráció fokát és a szolidaritás mértékét (loving), illetve az önmegvalósítás érzését vagy annak hiányát (being) mérte objektív és szubjektív változók segítségével. A szerző később kidolgozta koncepciója egyszerüsített formáját, melyben a szubjektív életminőséget a materiális, a szociális és a személyes fejlődés szükségleteit mérő objektív mutatók elégedettségi indikátorai képezték le (Allardt [1993]). Az egyéni értékelésen alapuló allardti teóriához hasonló elveken nyugodott az individuális jóllét (subjective well-being) észak-amerikai koncepciója. Az elmélet szerint a szubjektív jóllét tudományos megfogalmazása annak, ahogyan az emberek értékelik saját életüket és annak különbözö területeit. Az értékelésnek van egy kognitív és egy affektív oldala, melyben a kognitív oldal a viselkedés intellektuális, racionális, az affektív pedig az érzelmi és emocionális összetevője. A szubjektív jóllét tehát egy multidimenzionális definíció, melyben számos más, önmagában is többdimenziós fogalom (elégedettség, boldogság, érzelmi jóllét) kapcsolódik össze (Diener [1984], [1994]). Az említett definíciók és fogalmak tisztázásához szükséges röviden kitérni a lehatárolásokra. Utasi ([2002] 70-73. old.) szerint a jólét (welfare) megteremtése az elsősorban objektív indikátorokkal mért gazdasági fejlődést, anyagi javakkal való ellátottság javítását jelenti, míg a társadalmak minőségének másik oldalát az életminőségnek, az egyéni jóllétnek (well-being) a fejlődése mutatja meg, melynek alapja természetesen anyagi javakkal biztosítható, s melyet leggyakrabban 
szubjektív mutatók mérnek. A külföldi szakirodalomban az életminőség (quality of life) szükebb értelemben ,arra utal, hogy az egyén élete milyen mértékben éri el a kívánatos mértéket szemben a nem kívánatos állapottal, kizárólag a külső tényezőkre helyezve a hangsúlyt, úgy mint az életkörülmények vagy a jövedelem". Azonban a tágabb értelemben vett definíció „nem csupán az életkörülmények minőségét, hanem ezen életkörülményekre irányuló egyéni percepciókat, gondolatokat, érzéseket és reakciókat is magában foglalja" (Diener [2006] 401. old.). Ezért az életkörülményekkel kapcsolatos individuális percepciók együttesen a szubjektív életminőséget definiálják. ${ }^{3}$

A további elméleti megközelítések az individuális jóllét értelmezésében a gazdasági és társadalmi erőforrások szerepét helyezték elötérbe (Schulz [1995]; LengyelJanky [2002]; Utasi [2002], [2008]), míg más teóriák az erőforrások mellett az egyén képességeire hívták fel a figyelmet (Sen [1993]). Sen elmélete szerint nem az a meghatározó az egyéni jóllét mérésekor, hogy ki mennyi, illetve milyen jellegü javakkal, erőforrásokkal rendelkezik, hanem az, hogy ezeket a rendelkezésére álló javakat hogyan tudja felhasználni. Ez pedig nemcsak az egyén személyes képességeitől függ - a fizikai és a mentális képességeket szintén ideértve -, de ugyanúgy meghatározza a társadalmi és a fizikai környezet is. A társadalmi környezetnek és intézményeknek az egyéni jóllét alakításában betöltött szerepét vizsgálta Lane [1996]. Szerinte a jóléti állam feladata, hogy a lehető legnagyobb boldogságot érje el a lehető legtöbb ember számára. Írásában arra kereste a választ, hogy a fejlett országok intézményei, mint a demokratikus politikai rendszerek és a piacgazdaság mennyire szolgálják ezt a célt. Teóriája közgazdaságtani elveken alapul, magát a boldogságot olyan ,jószágnak” tekinti, amelyet az egyén más, ún. végső javak megszerzésével és fenntartásával érhet el, amelyek maguk jelentik annak forrását. Ezek: a szubjektív jóllét, az emberi fejlődés és az igazságosság. Amerikai és nyugat-európai adatokat elemezve Lane arra a következtetésre jut, hogy a fejlett társadalmakban a „barátság” és a ,jó családi élet" az egyéni jóllét két alapvető forrása, azonban a társadalmi tőke utóbbi évtizedekben bekövetkezett hanyatlásával és a szolidaritás csökkenésével magyarázza, hogy a jóléti országokban még mindig magas a boldogtalan emberek aránya.

Headey-Wearing [1989] elmélete - melyet dinamikus egyensúlyi modellként vezettek be - a boldogság és az élettel való elégedettség hosszú távú alakulásának elemzése során született meg. Ausztrál háztartáspanel-adatokat vizsgálva a kutatók megállapították, hogy minden ember rendelkezik egy rá jellemző átlagos szubjektív jóllétszinttel. Ez az érték egy adott terjedelmen belül mozog az egyén életútja során, amelytől csupán jelentős életesemények (például gyermekszületés, válás, házastárs elvesztése, munkanélkülivé válás) hatására tér el, de az adaptációnak köszönhetően,

\footnotetext{
${ }^{3}$ Jelen tanulmányban a szubjektív életminőség, a szubjektív jóllét, az egyéni jóllét és a jóllét fogalmakat azonos értelemben használjuk.
}

Statisztikai Szemle, 95. évfolụam 10. szám 
bizonyos idő elteltével visszatér az egyénre jellemző tartományba. Az elméletet, melyre a későbbi szakirodalom ,set-point” teóriaként hivatkozott, a kutatók később a német és a brit háztartáspanel-felvételeken is tesztelték, mely vizsgálatok hasonló eredményeket mutattak (Headey [2010], Headey et al. [2014]). Az ezredfordulón új megközelítésnek számított Veenhoven [2000] koncepciója, melyben egy $2 \times 2$-es mátrixban definiálta az életminőséget meghatározó fö összetevőket. Ezek az egyéntől függő és független életfeltételek, valamint a külső és a belső szempontok szerinti értékelések. Az első két feltételt a jó életkörülményeket biztosító, élhető természeti környezet, illetve az egyén képességei és készségei jelentik, melyek a jóllét megteremtéséhez nélkülözhetetlenek. A harmadik tényező az életfeltételektől függően elért életkörülmények külső értékelési szempontok szerinti aspektusa, például, hogy az egyén mennyire érzi hasznosnak az életét, akár azért, mert gyermeket nevel, vagy azért, mert jó állampolgárnak érzi magát. Míg a negyedik összetevő, a belső szürő alapján, az egyén saját szubjektív értékelése, hogy mennyire érzi az életét boldognak, mennyire elégedett a munkájával és élete egyéb területeivel.

A szubjektív jóllét vizsgálata a szociológia több szakterületén is a kutatások középpontjába került. Dow-Juster [1985] korai munkájukban az időfelhasználási mód szubjektív életminőségre kifejtett hatását elemezték. Szerintük minden ember fontossági sorrendet állít fel a különböző tevékenységei között, és ezek a preferenciák befolyásolják, hogy ki hogyan osztja be az idejét, tehát milyen időfelhasználási módot alakít ki önmaga számára. Ez a sajátos, egyénre jellemző használati mód pedig befolyásolja az egyén élettel való elégedettségének mértékét. A kutatók vizsgálatukban az egyének piaci és nem piaci tevékenységeit értékeltették abból a szempontból, hogy az mennyire élvezetes a számukra. A kapott pontokat megszorozták minden egyes tevékenységre fordított idővel, és az élvezetesen eltöltött időmennyiséget allokálva alakították ki kutatásuk központi mérőeszközét. Azonban vizsgálatuk kontraintuitív eredményt hozott, a teóriájuk tesztelésére kifejlesztett indikátor nem állt szoros kapcsolatban az élettel való általános elégedettséggel, így a szerzők arra a következtetésre jutottak, hogy az élvezetesen töltött idő mennyiségéből nem vezethető le a szubjektív jóllét mértéke. Más kutatások az elégedettséget az időhiány (time pressure) problémájával összefüggésben vizsgálták. Garhammer [2002] arra hívta fel a figyelmet, hogy az emberek az idejük feletti rendelkezést és az önmegvalósítás igényét életük minőségének legalább olyan lényeges aspektusának tartják, mint az anyagi javakkal való ellátottságot. Európai uniós országok adatait elemezve és azokat az Egyesült Államok és Japán adataival összehasonlítva megállapította, hogy az ipari társadalmakban az élet felgyorsult tempója mellett, tehát az időhiány ellenére nem csökkent sem az élettel való elégedettség mértéke, sem a boldogságérzet, sőt, a legaktívabb emberek voltak azok, akik a legnagyobb boldogságról számoltak be. Ez az összefüggés megállta a helyét mind az országok közötti összehasonlításban, mind individuális szinten. Eredményeit azzal magyarázta, hogy a fejlett országokban a 
gazdasági növekedés az életminőség javulását vonta maga után, mely egy intenzívebb társas-társadalmi életet eredményezett, ami az időhiány negatív hatásait kiegyenlítve egy eseménydús, élményekkel teli kikapcsolódással járó életformát és elégedettséget (heavy-going satisfaction) hozott létre.

Magyarországon az életminőség szociológiai vizsgálatai az 1970-es évek második felében kezdődtek, többek között a strukturális tényezök meghatározó szerepének vizsgálatával (Hankiss [1980]). A rendszerváltást követően az empirikus elemzések az élettel való elégedettség és a boldogság dimenziói alapján mért individuális jóllét mértékét vizsgálták objektív és szubjektív mutatók bevonásával, összefüggésben olyan társadalmi problémákkal, mint a szegénység, az anómia, a társadalmi integráció, a jövedelmi egyenlőtlenségek (Andorka [1996]; Andorka-Spéder [1996]; Spéder-Paksi-Elekes [1998]; Elekes-Paksi [2000]; Spéder-Kapitány [2002]; Utasi [2002], [2008]). Egyes kutatók az empirikus eredményeiket a referenciacsoportelmélettel (Sági [2000], Hajdú-Hajdú [2011]), mások az erőforrás-elmélettel (Lengyel-Janky [2002]) vagy egyes stresszfaktorok szerepével (Utasi [2011]) magyarázták. Az ezredfordulót követően az életminőség-kutatások a lakossági felvételek mellett speciális társadalmi csoportok vizsgálatára is kiterjedtek (Szabó [2003], Bernát et al. [2016]).

Jelen kutatás elméleti keretét Allardt korai majd későbbi koncepciója és Diener összetett szubjektív jóllét modellje alkotja (Allardt [1973], [1993]; Diener [1984]). Kifejezetten az allardti és a dieneri teóriák alapján kifejlesztett multidimenzionális szubjektív életminőség indikátorról a hazai szociológia terén nincs tudomásunk, ezért a tanulmány hozzáadott értékét egyrészt e több változóra érzékeny összetett mutató kidolgozása adja, másrészt a magyar lakosság szubjektív életminőségének ezen új, többdimenziós mutató szerinti vizsgálata a gazdasági válság időszakában. További újszerüsége az elemzésnek az affektív jóllét alakulásának nemzetközi összehasonlító vizsgálata az európai országok körében, a válságból való kilábalás éveiben.

\section{Adatok és módszerek}

Az elemzéshez az adatokat az ESS keresztmetszeti felvételei biztosították. Az adatfelvétel alapját egy standard, minden országban azonos kérdőív képezte, melyhez minden alkalommal más és más témakörök kiegészítő moduljai csatlakoztak, bizonyos időközönként rotálódva, ahogy 2006-ban és 2012-ben a „Személyes és társadalmi jóllét" (Personal and social wellbeing) modulja. A mintát véletlenszerü mintavétel alapján választották ki minden országban. Az empirikus elemzéshez az adatfelvételt hazánkban a Magyar Gallup Intézet készítette el 2006. november 21. és 
2007. január 28. közötti időtartamban $(N=1518$ fö), míg a 2012-es felvételt a TÁRKI Társadalomkutatási Zrt. 2012. november 11. és 2013. február 17. között $(N=2014$ fö). A magyar adatokat azzal a súlyváltozóval súlyoztuk, mely korrigálja, hogy az adott ország egyes válaszadói az alkalmazott mintavételi eljárás folytán eltérő valószínúséggel kerüljenek a mintába. A nemzetközi elemzésnél minden adatállomány esetén a meghatározott hullámhoz tartozó keresztmetszeti súlyozást alkalmaztuk. Itt a súlyváltozót az említett és a lakosságszám súlyváltozó kombinációjaként hoztuk létre, az ESS-dokumentációban leírtaknak megfelelően. ${ }^{4} \mathrm{~A}$ többdimenziós életminőség indikátort főkomponens-elemzés eljárással alakítottuk ki. ${ }^{5}$

\subsection{Szubjektív életminőség}

A kutatás során kifejlesztett többdimenziós szubjektív életminőség indikátor öt összetevőből épült fel a következők szerint. Egyrészt Allardt 1993-as modellje alapján, a „having, loving, being” dimenziókat egy-egy kérdéssel operacionalizáltuk: a „having” dimenzió esetében az életszínvonallal való elégedettséggel, a „loving” dimenziónál a beágyazottság mértékéből eredő támogatottságérzettel, míg a „being” dimenzió esetében az önmegvalósítás érzettel. Másrészt Allardt korai modelljében a faktorokon elszórtan megjelenő azon érzéseket (feelings of well-being) képeztük le, amelyekkel Diener a szubjektív jóllét affektív oldalát mérte: a globális boldogságérzetet, illetve az időszakos pozitív-negatív emóciókat (Allardt [1973], Diener [1984]). A kérdőívek rotációs kérdésblokkjai a fő szükségletdimenziókat tartalmilag megfelelően megragadó kérdéseket tartalmazták, azonban az életszínvonallal való elégedettség kérdését a 2012-es kérdőív már nem kérdezte, csupán az élettel való elégedettséget. A szakirodalomban egy korai életminőség-koncepció (top-down approach) szerint az embereknek az életükkel való általános elégedettség érzése az elsődleges, ez az, ami meghatározza, mennyire elégedettek életük egyes részterületeivel (AndrewsWithey [1974]). Továbbá az élettel való általános elégedettséget felfoghatjuk úgy is, mint az egyes életterületekkel való elégedettség aggregált mutatóját (Van Praag et al. [2001]), amely így az anyagi körülmények értékelését is magában foglalja. Allardt a „having” dimenziót az 1993-as szubjektív modelljében az életkörülményekkel való elégedettséggel definiálta. Így a kutatásban e három szakirodalmi szempont alapján az élettel való elégedettség az életkörülményekkel való elégedettség közvetett indikátoraként szerepel. A vizsgálathoz kifejlesztett szubjektív életminőség index tehát

\footnotetext{
${ }^{4}$ Az adatfelvételről, a mintavételi eljárásról, a súlyozásról és egyéb technikai kérdésekről részletes tájékoztatást ad a kutatás dokumentációja, mely elérhető az ESS honlapján (http//:www.europeansocialsurvey.org).

${ }^{5}$ A legfontosabb statisztikákon és hivatkozásokon túl a továbbiakhoz (például hiányzó esetek ellenőrzése) lásd az értekezéstervezetet (Ivony [2017]), a helyhiány miatt itt nem közölt, de az eredményeket bemutató kétváltozós elemzések táblázataival, statisztikáival és diagramjaival együtt.
} 
1. az élettel való elégedettségérzetet, 2 . a támogatottságérzetet, 3 . az önmegvalósításérzetet, 4. a boldogságérzet és 5 . a pozitív-negatív érzések balanszát fogja át, melyeket a következő kérdésekkel operacionalizáltuk (az érzelmi balansz kérdéseire későbbiekben térünk ki): 1. Mindent összevetve mennyire elégedett mostani életével?; 2. Vannak olyan emberek az életemben, akik igazán törődnek velem. (2006); Milyen mértékben kap segítséget és támogatást az Önhöz közel állóktól, amikor szüksége van rá? (2012) ${ }^{6} ; 3$. Úgy érzem, amivel foglalkozom az életemben, az értékes és megéri a fáradtságot.; 4. Mindent egybevetve mennyire érzi magát boldognak? Az 1. és 4. számú kérdések esetében a megkérdezettek 11 fokú skálán értékelhették életüket a „Teljesen elégedetlen”, illetve „Nagyon boldogtalan” (,0”) kategóriától a „Teljesen elégedett” és „Nagyon boldog” („10-es”) kategóriáig. A 2./2006 és 3. számú kérdések esetében a válaszokat ötfokú Likert-skálán vették fel, melyek az 1-es „Teljesen egyetért” értéktől az 5-ös „Egyáltalán nem ért egyet” értékig terjedtek. Ezen kérdések irányát megfordítottuk, így amikor a válaszok magasabb skálaértéket mértek, az azt jelentette, hogy a válaszadó magasabb szinten tudja realizálni a szociális és a személyes fejlődés szükségleteit. A 2./2012 kérdést hétfokú skálán mérték a nulla „Egyáltalán nem” értéktől a 6-os „Teljes mértékben” válaszlehetőségig.

Visszatérve tehát az emóciókhoz, a korai allardti modell - az észak-amerikai szakirodalom szerint tartós percepciónak tekintett átfogó boldogságérzet (Diener et al. [1999], Kim-Prieto et al. [2005]) mellett - több olyan kérdést is tartalmazott, melyek rövid távú, átmeneti érzéseket is mértek (például a magányt, a nyugtalanságot, a különböző frusztrációkat). A kutatásban ezen érzések társadalmi vagy egyéni hátterét nem vizsgáljuk, azonban a pozitív és a negatív tartalmú időszakos érzések előfordulását, mint a szubjektív életminőséget meghatározó tényezőket figyelembe vesszük. Ennek elsődleges oka, hogy a válság éveiben bekövetkezett egyéni életvitelbeli, életmódbeli változások folyamatosan átmeneti frusztrációkat, aggodalmakat, stresszt váltottak ki az egyénekben, melyek különböző tartalmú érzésekben eltérő gyakorisággal csapódtak le a mindennapi életük során (European Commission [2014]). A szakirodalom szerint azonban a rövid távú érzelmi állapotok mérésekor elegendő néhány általános, pozitív és negatív tartalmú emóciót vizsgálni a helyett, hogy nagyszámú, speciális érzéseket megragadó mutatókkal dolgoznánk, tekintettel arra, hogy azokat a megkérdezettek ritkábban és kisebb előfordulási gyakorisággal élik meg (Diener et al. [2010]). Ezért az életminőség index a következő két pozitív és két negatív, általános, egymás ellentétpárjaként meghatározható érzelmi állapotok bekövetkezésének gyakoriságát mérö változót tartalmazza: $a$ ) Múlt héten milyen gyakran élvezte az életet?; $b$ ) Múlt héten milyen gyakran volt levert?; c) ...milyen gyakran volt nyugodt, békés?; $d$ ) ...milyen gyakran volt nyugtalan? A kérdésekre négyfokú skálán adhattak választ a megkérdezettek, a következők szerint: $1=$ „,Soha vagy szinte soha”, $2=$ „Néha”, $3=$ „,Többnyire”, 4 = „Mindig vagy

${ }^{6}$ A két kérdés más megfogalmazásban ugyan, de a támogatottságérzetet méri. 
majdnem mindig". Az ellentétes töltetü emóciókat a szakirodalomban leggyakrabban egy önálló pozitív és egy önálló negatív érzéseket mérő skálán aggregálják, vagy egy érzelmi balanszot mérő mutatót hoznak létre a korai Bradburn-skála alapján (Bradburn [1969], idézi: Diener [1984]). Az önálló mutatók kialakításához alacsony volt a kérdőívben szereplő pozitív tartalmú kérdések száma, ezért az említett módszer alapján egy egyszerủ szummatív skálát dolgoztunk ki. ${ }^{7}$ Az attitüdskála pozitív értékei pozitív érzelmi egyenleget (a válaszadó több pozitív érzést tapasztalt meg, mint negatívat az elmúlt héten), negatív értékei negatív egyenleget jelentettek.

Ezt követően a having, loving, being dimenziók, illetve a jóllét tartós és átmeneti érzéseit mérő mutatók bevonásával készült el a szubjektív életminőség kompozit mutatója, főkomponens-elemzés eljárással. ${ }^{8} \mathrm{~A}$ látens változó pozitív értékei azt jelentik, hogy az egyén magasabb szinten realizálja az alapvető szükségleteit, így a mutatón elért magasabb pontok kedvezőbb életminőséget fejeznek ki, míg a negatív indexértékek alacsonyabb realizációs szintet és életminőséget mérnek.

\subsection{A magyarázóváltozók}

a) A szakirodalom szerint az életminőséget alapvetően a társadalmi integráció foka és az egyén integráltságérzete határozza meg, melynek két fö területe a család és a munkaerőpiac (Utasi [2002], [2008]; Frey-Stutzer [2003]). A családban való integráltságot a családi státus változója mérte, mindkét évben a következö kategóriákkal: házas/törvényes élettársi kapcsolatban él, elvált, özvegy/élettársa meghalt, hajadon/nőtlen. A munkaerőpiaci jelenlét esetében a 2006-os kérdőív kétféle kérdést alkalmazott: a hagyományos „Mi a jelenlegi foglalkozása?”; és az elmúlt hét jellemző tevékenysége alapján: „A következők közül melyikkel jellemezhető az, amit Ön az elmúlt 7 napban csinált?”. Az utóbbit a következö válaszkategóriákkal rögzítették: dolgozott/fizetett munkát végzett, tanult, munkanélküli volt (aktívan keresett/nem keresett munkát), tartósan beteg vagy rokkant, nyugdíjas, háztartásbeli vagy más jellemző tevékenysége volt. Tekintettel arra, hogy a 2012-es kérdőívben kizárólag a jellemző tevékenységet kérdezték, így mindkét évben ezt alkalmaztuk.

b) A szubjektív életminőséget meghatározzák az egyén egészségi állapotára, illetve fizikai biztonságára vonatkozó percepciói, valamint az, ahogyan szubjektív jövedelmi helyzetét értékeli, mely egyéni értékelések a szakirodalom szerint pozitív összefüggés-

\footnotetext{
${ }^{7}$ Az érzelmi egyenleget mérő skála -6 és +6 között vett fel értékeket, 2006-ban $(N=1476)$ a mutató átlaga és szórása 1,402 (2,459), míg 2012-ben $(N=1963)$ 1,462 (2,333) volt. A balansz skála megbízhatóságát mérő Cronbach-alfa mutató értéke mindkét évben megfelelően magas volt $(0,800 ; 0,795)$.

${ }^{8}$ Az eljárás mindkét évben egy-egy magas sajátértékkel rendelkező faktort (standardizált változót) eredményezett 51,1 és 52,5 százalékos négyzetes faktorsúlyokkal és 0,775; 0,766 KMO-értékekkel, mely statisztikák elfogadhatók.
} 
ben állnak a jóllét mértékével (Michalos-Zumbo [2002], Spéder-Kapitány [2002], Lengyel-Janky [2002]). Több vizsgálat felhívta a figyelmet a szubjektív jóllét és a személyes beállítottság összefüggésére, melyekben az optimizmus minden esetben pozitív kapcsolatot mutatott a boldogsággal és az élettel való elégedettséggel (DienerLucas [1999], Wrosch-Scheier [2003]). A válságok általános következménye a társadalomban érzékelhető kisebb vagy nagyobb fokú anómia, a normaszegés elfogadottságának, az elidegenedés érzetének és a dezorientációnak az elterjedtsége (Durkheim [1982]), mely kutatásonként eltérő változókból kialakított többdimenziós egyéni szintü anómia és elidegenedés indikátorként minden esetben fordított kapcsolatban állt a boldogsággal (Andorka [1996], Spéder et al. [1998], Spéder-Kapitány [2002]). Ezeket a szubjektív területeket jelen kutatásban a következő változókkal specifikáltuk: „Milyen az Ön általános egészségi állapota?”, „Milyen biztonságos ezen a környéken sötétedés után egyedül sétálni?”, továbbá „Melyik leírás közelíti meg leginkább az Önök háztartásának jelenlegi jövedelmi helyzetét?” és „Optimistán tekintek a jövőre.”. Az egészségi állapotukat a megkérdezettek a nagyon jó (1), jó (2), kielégítő (3), rossz (4), és nagyon rossz (5) fokozatok szerint, a lakókörnyékhez kapcsolódó biztonságérzetüket a nagyon biztonságos (1), biztonságos (2), nem biztonságos (3), egyáltalán nem biztonságos (4) kategóriák segítségével értékelhették, míg a szubjektív jövedelmi helyzetüket a kényelmesen megélünk (1), kijövünk (2), nehezen (3), nagyon nehezen élünk meg (4) kategóriákkal. Az optimista beállítottságot ötfokú skálán vették fel (1-es „Teljesen egyetért”, 5-ös „Egyáltalán nem ért egyet”). Az egyéni anómiát és elidegenedést mérő skálát az egy irányba forgatott következő alskálákból, szummatív mutatóként alakítottuk ki: 1. „Legtöbbször úgy érzem, hogy van értelme annak, amit csinálok.” (inverze: értelmetlenségérzet); 2. „Múlt héten milyen gyakran érezte magányosnak magát?” (elmagányosodás); 3. „Mennyire érzi, hogy segítőkészek az emberek a közvetlen környezetében?” (inverze: elszigeteltségérzet); 4. „A mindennapokban ritkán adódik lehetöségem arra, hogy megmutassam, mire is vagyok képes." (haszontalanságérzet). Az 1. és 3. számú kérdésre a megkérdezettek ötfokú Likert-skálán adhattak választ. A 2. számú kérdések esetében a válaszokat négyfokú skálán rögzítették: az 1 = „Soha vagy szinte soha”, $2=$ „Néha”, $3=$ „,Többnyire”, 4 = „Mindig vagy majdnem mindig” válaszkategóriákkal. A 4. számú kérdésnél a válaszokat 0 -tól („,egyáltalán nem”) 6-ig terjedö („,nagyon”) hétfokú skálán vették fel.

c) A szociodemográfiai tényezők szerinti társadalmi csoportok vizsgálatához kapcsolódóan a nem, az életkor, a településtípus, az iskolai végzettség és a jövedelem változói szerepelnek az elemzésben. Az életkort a megkérdezettek születési éve alapján rögzítették a felvétel során, amelyet az életkor és a szubjektív jóllét U alakú kapcsolata miatt hatértékủ változóvá alakítva, a következő életkori csoportokat alakítottuk ki: 30 évtől fiatalabbak, 30-39, 40-49, 50-59, 60-69 évesek, és 70 éves és idősebbek. Az önbesorolásos településtípusnál az első kettő és az utolsó kettő kategóriát összevonva háromértékủ változót hoztunk létre: 1 =nagyváros és elővárosa, 
2 = város vagy kisváros, 3 = falu-község-tanya. Az iskolai végzettség esetében mindkét magyar kérdőív hasonló többkategóriás változót alkalmazott, itt a négykategóriás változót vettük alapul: alapfokú vagy alacsonyabb iskolai végzettség, szakmunkás/szakiskola, érettségi, felsőfokú. A jövedelem esetében a kérdőív a háztartás összes forrásból származó, havi nettó bevételére kérdezett rá. Az empirikus vizsgálat elemzési egysége azonban nem a háztartás, hanem az egyén volt, így a jövedelemkategóriák átlagának és a háztartásban élők számának hányadosa alapján az egy före jutó nettó havi háztartási jövedelem változóját hoztuk létre. A 2006-os évben a mintában a jövedelem kérdés megválaszolását 189 fö utasította vissza, 75 esetben pedig „,nem tudom” választ rögzítettek (összesen 264 fö). 2012-ben az előbbi kategória 483 főt, míg az utóbbi 109 főt számlált (összesen 592 fö), mely eseteket kizártuk.

\section{Eredmények: kétváltozós összefüggések - a többdimenziós szubjektív életminőség index elemeinek jellemzői a gazdasági válság elött és azt követően}

Jelen fejezetben a szubjektív életminőséget mérő multidimenzionális mutató elemeinek viselkedését vizsgáljuk a fő társadalmi-demográfiai csoportokban (nem, életkor, településtípus, iskolai végzettség, családi állapot, munkaerőpiaci jelenlét) és a szubjektív magyarázóváltozók (szubjektív egészség, biztonságérzet, szubjektív jövedelem, optimista beállítottság) szerint.

\subsection{A „having” dimenzió realizációja}

A materiális szükségletek dimenzióját a korábbiakban leírtak alapján az élettel való elégedettséggel, mint közvetett indikátorral mértük. Korábbi hazai vizsgálatok elégedetleneknek a 11 fokú skála 0-tól 3-ig terjedő kategóriáit, elégedetteknek pedig a 7-10-es értékkategóriákat megjelölő válaszadókat tekintették (Andorka-Spéder [1994], [1996]). Jelen kutatásban elégedettnek tartottuk azokat, akik a 11 fokú skálán 6-tól 10-ig, míg elégedetlennek, akik 0-tól 4-ig terjedő fokozatok alapján értékelték az életüket. ${ }^{9}$ E szerint a válság elött, 2006-ban a lakosság 62,5 százaléka volt elégedett és 17,5 százaléka elégedetlen az életével, míg 2012-ben ez az arány 54,4 és 30,2 százalékra változott. A mintabeli főarányokhoz képest mindkét évben szignifikánsan

\footnotetext{
${ }^{9}$ A csoportátlagok összehasonlításához a Kramér-féle V-mutatót használtam, mely a $\chi^{2}$-statisztika értékéhez kapcsolódó szimmetrikus mutató, az együttható a két változó közötti kapcsolat erősségét fejezi ki, és akkor értékelhető, ha a változók közötti összefüggés statisztikailag szignifikáns.
} 
magasabb az elégedettek aránya a 30 év alattiak, a felsőfokú végzettségúek, az aktívak, a ,jó és nagyon jó" szubjektív egészségi állapotnak örvendők, az optimista szemlélettel rendelkezők és magukat a lakókörnyezetükben biztonságban érző lakosok, valamint azok között, akik kijönnek vagy kényelmesen megélnek a jövedelmükböl. Gyakrabban találtunk elégedetleneket az alapfokú vagy alacsonyabb és szakmunkás végzettségüek, az inaktívak, a „rossz és nagyon rossz” egészségi állapotúak, a pesszimisták és a fizikai biztonság hiányát érzékelők körében, továbbá azok között, akik nehezen vagy nagyon nehezen éltek meg a háztartásuk havi bevételeiből. Az eltérő településtípusok lakosainak realizációs szintjei 2006-ban nem tértek el a föarányoktól, 2012-ben azonban a nagyvárosban vagy annak elővárosában élők többen vallották magukat elégedettnek, mint a teljes mintában. A krízis előtt a házasok inkább elégedettek, az egyedülállók inkább elégedetlenek voltak, a válság után azonban a csoportarányok nem különböztek szignifikánsan.

\subsection{A „loving” dimenzió realizációja}

A dimenzió a szeretet, a kölcsönös törődés és támogatás létét, együttesen a támogatottságérzetet fejezi ki. Azokat tekintettük a szükséglettípust magas szinten realizáló válaszadóknak, akik az ötfokú skálán „teljesen egyetért” és ,egyetért” választ adtak, illetve 2012-ben a hétfokú skála 5-től 7-ig terjedő értékeit választották, azokat pedig alacsony szinten realizálóknak, akik a „nem ért egyet” és „egyáltalán nem ért egyet”, illetve a 0-2 skálafokokat jelölték meg. Mindkét évben a lakosság jelentős része támogatottságérzetről számolt be, 2006-ban a minta 89,1, 2012-ben 87 százaléka értékelte úgy, hogy számíthat törődésre és segítségre, míg 3,3 és 4,9 százalék volt azok aránya, akik erre nem számíthattak a hozzájuk közelállóktól. Az eredmények alapján elsősorban a fiatalok, a diplomások, a jövőbe bizakodóan tekintők, az egészségi problémák nélkül élők és azok realizálták magas szinten e szükséglettípust, akik kényelmesen megéltek a jövedelmükből. Míg a képzetlenek, a munkanélküliek, tartósan betegek vagy rokkantak és egyéb inaktívak voltak azok, akik jellemzően nem számíthattak támogatásra és törödésre, ahogyan a jövőben nem bízó, borúlátó és rossz általános egészségi állapotban levő lakosok sem. A nem, a településtípus és a biztonságérzet szerinti csoportok nem mutattak szignifikáns eltérést a szükséglettípus mintabeli megoszlásához képest.

\subsection{A ,being” dimenzió realizációja}

A személyes fejlődés szükségletét mérö kérdés esetében, a korábbiakhoz hasonlóan, a teljesen egyetértőket és az egyetértőket tekintettük önmegvalósítóknak. A megkérdezettek között 72,3 (2006) és 66 százalék (2012) volt azok aránya, akik ebbe 
a kategóriába sorolták magukat, míg csupán 6,5 és 9,6 százalék érezte úgy, hogy nem tudott kiteljesedni az életében (akik a „,nem ért egyet”, „egyáltalán nem ért egyet” skálafokokat választották). Az önmegvalósítók között mindkét évben szignifikánsan többen voltak a magasan kvalifikált, mindennapi anyagi problémáktól mentes életet élők, mint a teljes mintában, továbbá azok is, akik optimista szemlélettel rendelkeztek és úgy érezték, hogy az egészségükkel nincs probléma. Azok között pedig, akik önmegvalósításuk hiányáról adtak számot, a válság előtt és azt követően is nagyobb arányban fordultak elő alacsony erőforrás-ellátottsággal rendelkező csoportok tagjai (képzetlenek, inaktívak, rossz egészségi állapotban lévők), továbbá pesszimisták. Amíg a nem és a településtípus eltérő csoportjai nem mutattak szignifikáns eltérést az önmegvalósítás eltérő realizációs szintjeiben a teljes mintabeli arányokhoz képest, addig a korcsoportoknál 2012-ben a 30-39 évesek között gyakrabban fordultak elő önmegvalósítók.

\subsection{Boldogság}

A boldogság esetében a szükséglettípust magas szinten realizálók (6-tól 10-ig), illetve alacsony szinten realizálók csoportjairól (0-tól 4-ig) a következők mondhatók el. Az eredmények alapján 2006-ban 63,9, 2012-ben 61,5 százalék volt azok aránya, akik életüket globálisan boldognak értékelték, míg 17,1 és 21,4 százalék azoké, akik boldogtalannak. A gazdasági válság időszakában a boldogság ,jószágot” magas szinten értékelők jellemzően a kvalifikált, a 30 év alatti fiatal felnőttek, a házasságban vagy élettársi kapcsolatban élők és a munkaeröpiacon jelenlévők realizálták, továbbá azok, akik biztonságérzetről adtak számot, kedvező általános egészségről számoltak be, mindennapi megélhetési gondok nélkül éltek és optimistán tekintettek a jövőbe. A szükséglettípust alacsony szinten realizálókat a válság előtt az inaktívak, az idősebbek, az alulképzettek, az egészségi problémákkal élők, illetve a biztonsághiányt szenvedők és azok körében találtunk jellemzően, akik nagyon nehezen éltek meg a havi bevételeikböl. Boldogtalanok a válságot követöen is ezen utóbbi csoportokban fordultak elő szignifikánsan nagyobb arányban, mint a teljes mintában.

\subsection{Pozitív-negatív érzelmi egyenleg}

A hétköznapi frusztrációk gyakorisága szintén hozzájárul ahhoz, hogy napjaink mennyire nyugodtak vagy nyugtalanok, mennyire élvezzük az életünket, vagy vagyunk levertek, depressziósak. Az időszakos és eltérő tartalmú emóciók mérlegét mérő balansz skála segítségével két csoportot választottunk el egymástól, azokat, akik az átlag feletti, vagyis pozitív érzelmi egyenleget, és akik átlag alatti, tehát ne- 
gatív egyenleget mutattak. Pozitív egyenleget a minta 53,2 (2006) és 52,9 (2012) százaléka mutatott, a negatív balansz a skála másik fele alapján 46,8 és 47,1 százalék volt. (A továbbiakban a pozitív egyenleg csoportjába tartozókat viszonyítjuk a teljes mintához.) Mindkét évben pozitív érzelmi balanszot jellemzően a fiatalok, a biztonságérzettel rendelkezők, az optimisták, illetve a magas erőforrás-ellátottsággal rendelkező csoportok tagjai körében mértünk, továbbá valamivel többször a férfiak és a házasságban vagy élettársi kapcsolatban élők között.

A szignifikáns kapcsolatok erősségéröl összességében a két időpontban felvett adatok alapján az eltérő társadalmi-demográfiai csoportok szerint a következők mondhatók el: a nem, az életkor és a családi állapot esetében általában hasonló erősségű kapcsolatokat mértünk mindegyik fö dimenzióban, mindkét évben. Az iskolai végzettség szerint mind az öt dimenzióban erősebb kapcsolatot találtunk 2012-ben, mint 2006-ban, míg a munkaerőpiaci jelenlét szerinti csoportokban négy dimenzióban szintén erősebb, a „loving” dimenzió esetében azonban gyengébb volt az összefüggés. A szubjektív egészségi állapot szerinti csoportokban a két időszak között az öt dimenzióban hasonló erősségű együttjárást mutattak a statisztikák. A biztonságérzet csoportjainál az összefüggések 2012-re valamelyest veszítettek erejükből, míg a személyes beállítottság és a szubjektív jövedelem csoportjainál mind az öt dimenzióban a válságot követően erősebb volt a kapcsolat, mint 2006-ban. Az összefüggések erősségének változása több hipotetikus magyarázatot vet fel, így egyrészt köszönhető egy ún. periódushatásnak, mely feltehetően minden társadalmi csoport esetében csökkenthette a jóllét mértékét, másrészt köszönhető annak, hogy csupán bizonyos társadalmi csoportok esetében következett be változás (arányok változása: több lett a munkanélküli), de valószínüleg köszönhető annak is, hogy a sérülékenyebb társadalmi csoportoknál (egyszülös családok, alacsony jövedelmüek) a válság következményei több stresszt, aggodalmat és frusztrációt okoztak, mint más csoportok esetében (European Commission [2014]). Természetesen az említetteken túl egyéb hipotetikus magyarázatok is felmerülhetnek.

\section{A szubjektív életminőség alakulása az egyes társadalmi-demográfiai csoportokban a gazdasági válság előtt és azt követóen}

Az előző fejezetben az összetett életminőség index elemeinek viselkedését vizsgáltuk az eltérő szükséglettípusokban elért realizációs szintek alapján a magyar lakosság körében. Ebben a fejezetben az öt dimenzió által együttesen mért individuális 
jóllét alakulásának elemzésére térünk ki eltérő társadalmi metszetekben. ${ }^{10} \mathrm{Az}$ életkor a szubjektív életminőséggel fordított kapcsolatot mutatott, annak emelkedésével csökkent a szubjektív jóllét mértéke. Korcsoportok szerint 2006-ban a 30 év alattiak értek el átlagostól magasabb életminőséget, azonban 2012-ben a 30-39 éves fiatal felnőttek is pozitívabb értékelést adtak. A válság előtt kedvezőtlenebb életminőséget az idősebbek, elsősorban az 50-59 évesek körében, míg a válság éveit követően a 70 évesnél idősebbek között mértünk. (Lásd a 2. ábrát.)

2. ábra. A szubjektiv életminőség index és az életkor összefüggése
a) 2006. év
b) 2012. év
$(N=1427$ fó $)$
$(N=1905$ fö $)$
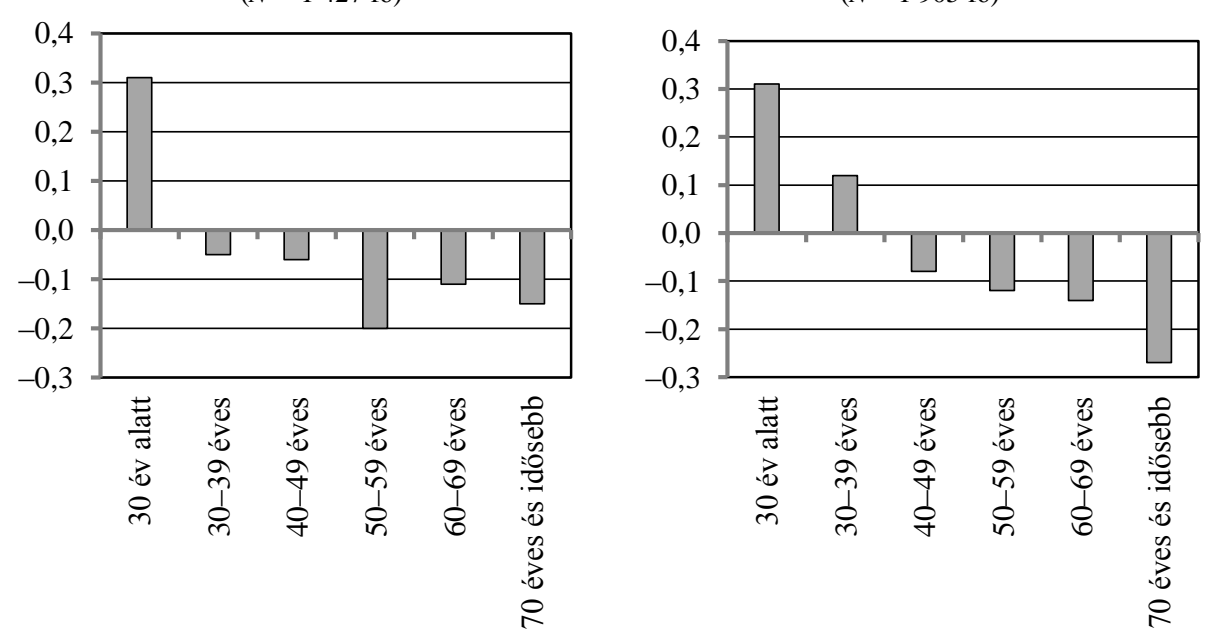

Megjegyzés. Az átlagtól való eltérések 1 százalékos szinten szignifikánsak mindkét évben, ahogyan a többi magyarázóváltozó esetében is.

Az integráltság mértékét és a szubjektív életminőség kapcsolatát a családi állapot és a munkaerőpiaci jelenlét függvényében vizsgáltuk meg. Az adatok azt mutatják, hogy az egyedülállók, vagyis az elváltak és azok, akik felbontották élettársi kapcsolatukat, illetve az özvegyek, valamint akik élettársa elhunyt, átlag alatt értékelték egyéni jóllétüket mindkét évben. Kivételt képeznek az egyedülállók körében a nőtlenek/hajadonok, akik lakossági átlagtól kedvezőbb életminőséget tudtak elérni a válság előtt és azt követően is. Hasonlóan kedvezőbb jóllét jellemezte a házasokat/élettárssal élőket, akik feltehetően a házasságból/élettársi kapcsolatból származó egzisztenciális és pszichés előnyöknek köszönhetően 2012-ben is átlagostól magasabb indexpontszámot érhettek

${ }^{10}$ A lakossági átlagtól való eltérést a $Z$ standardizált mérőszám mutatja, mely az adott populáció átlagától (0) az egyes független változókategóriák átlagos eltéréseit méri. A lakossági átlaghoz viszonyítva a pozitív eltérés átlagtól kedvezőbb, a negatív eltérés átlagtól kedvezőtlenebb szubjektív életminőséget jelent. 
el. A legrosszabb értékelést 2006-ban azok a megkérdezettek adták, akik jogilag házasságban éltek, vagy törvényes élettársi kapcsolatuk volt, de különéltek, mely kategória 2012-ben nem került a felvételbe. (Lásd a 3. ábrát.)

3. ábra. A szubjektiv életminöség index és a családi állapot kapcsolata

a) $2006 . e ́ v$
$(N=1429$ fó $)$

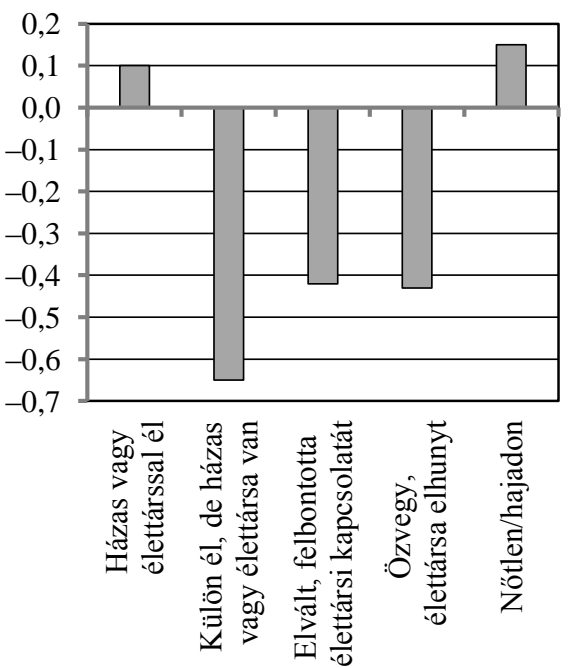

b) 2012. év

$(N=1863$ fó)

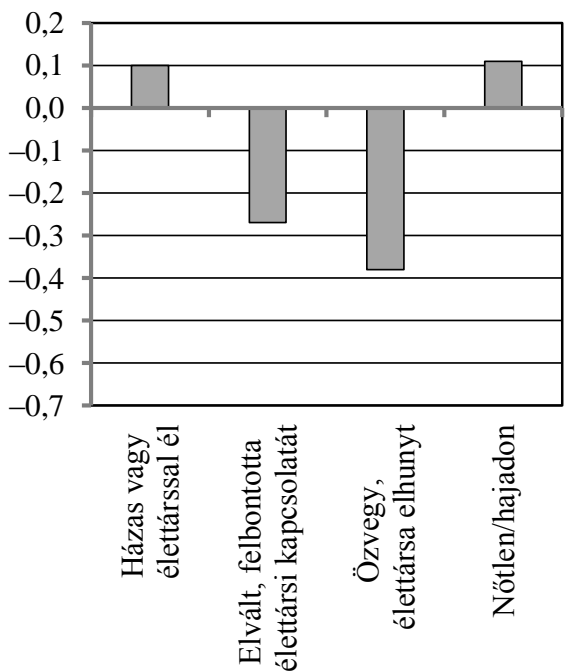

4. ábra. A szubjektiv életminőség index és az elmúlt héten végzett jellemzö tevékenység összefüggése

a) 2006. év

$(N=1510$ fö $)$

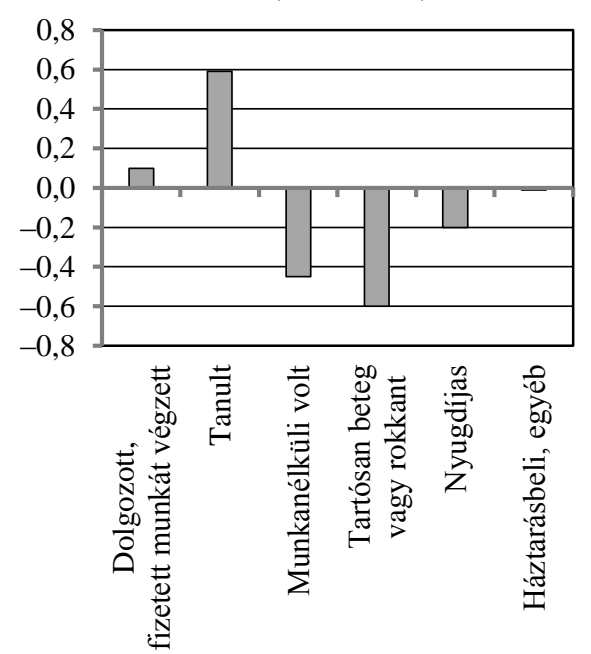

b) 2012. év

$(N=1888$ fö $)$

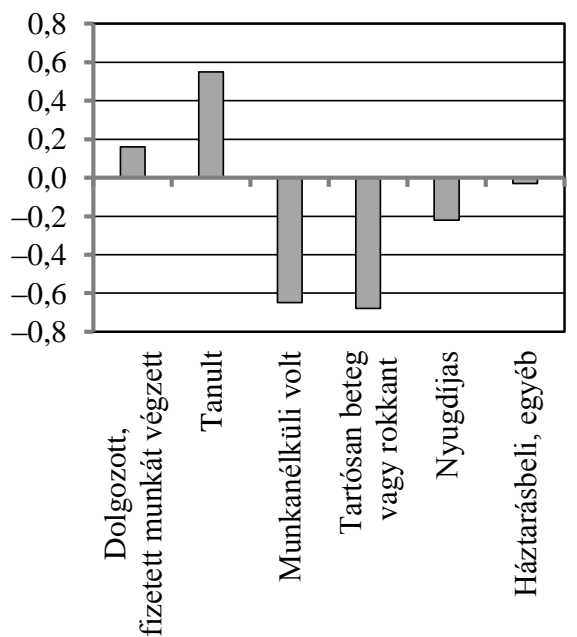


Az előző héten jellemzően végzett tevékenység alapján átlagostól jóval kedvezőbb szubjektív életminőségről a diákok adtak számot, míg azok, akik dolgoztak, átlagot alig meghaladó pontszámot értek el a válság elött és azt követően is. A nyugdíjasok, a munkanélküliek és a tartósan betegek vagy rokkantak alacsony indexértéke várakozások szerinti, azonban az utóbbi két csoport életminősége 2012-ben messze a legalacsonyabb. (Lásd a 4. ábrát.)

Az iskolai végzettség pozitív kapcsolatot mutatott a szubjektív életminőséggel, a képzettség emelkedésével az életminőség index egyre magasabb értékeket vett fel, a válságot követően az alapfokú vagy kevesebb iskolai végzettséggel rendelkezők életminősége volt a legkedvezőtlenebb. (Lásd az 5. ábrát.)

5. ábra. A szubjektiv életminöség index és az iskolai végzettség kapcsolata

$$
\begin{gathered}
\text { a) 2006. év } \\
(N=1431 \text { fö })
\end{gathered}
$$

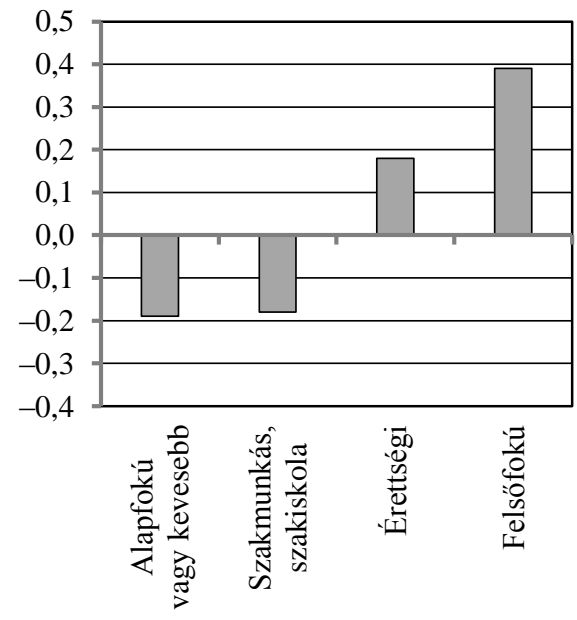

b) 2012. év

$(N=1901$ fö $)$

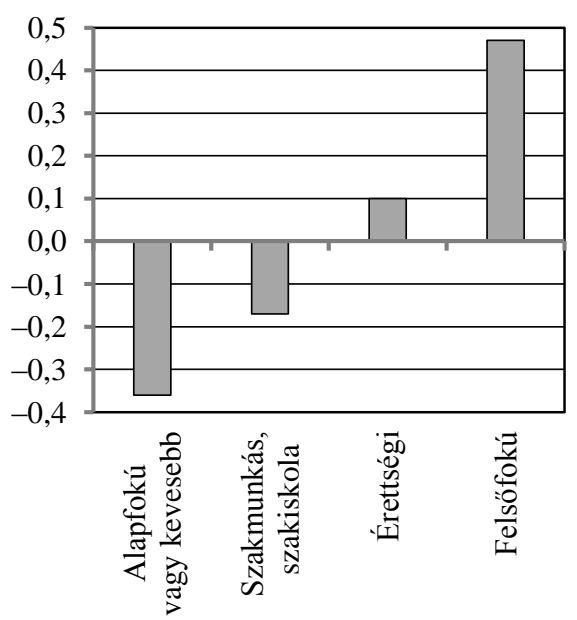

A szubjektív magyarázóváltozók alapján kialakított társadalmi csoportok életminősége a két évben hasonló tendenciát mutatott. Azok, akik úgy érezték, nehezen, vagy nagyon nehezen jönnek ki a háztartásuk havi bevételeiből az átlagostól alacsonyabb, míg akik kijönnek, vagy mindennapi anyagi gondok nélkül kényelmesen megélnek, átlagostól magasabb jóllétről számoltak be. Az egyéni értékelés alapján a problémáktól mentes általános egészségi állapot lakossági átlagtól kedvezőbb életminőséggel járt együtt. Azonban a rossz, de elsősorban a „nagyon rossz” értékelést adó lakosok indexértéke mindkét évben jelentősen elmaradt az átlagostól. (Lásd a 6. ábrát.) 
6. ábra. A szubjektiv életminöség index és a szubjektív egészségi állapot összefüggése

a) 2006. év

$(N=1432$ fö $)$

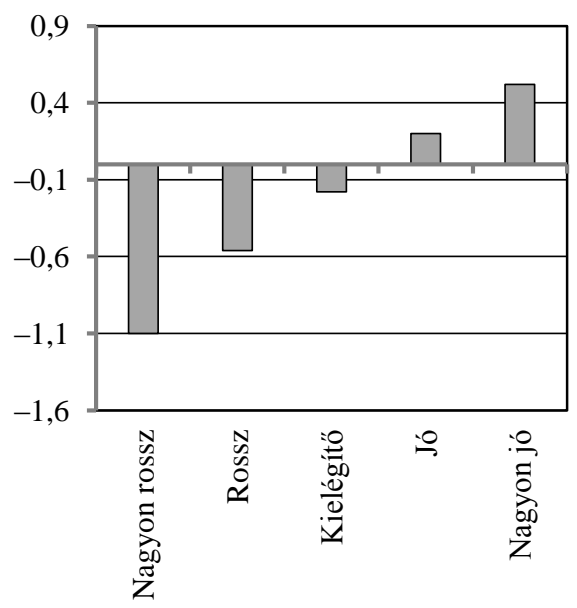

b) 2012. év

$(N=1905$ fö $)$

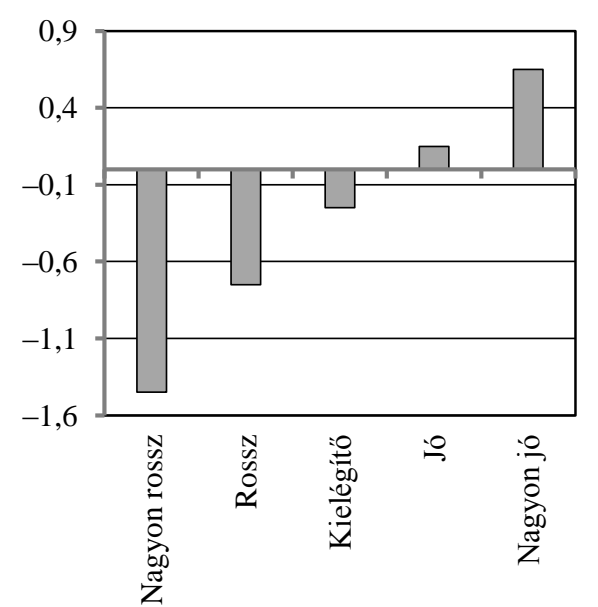

Hasonló tendenciákat figyelhettünk meg a szubjektív életminőség és a biztonságérzet, illetve a személyes beállítottság összefüggésében mind a válság előtt, mind a kilábalás időszakában. Ott, ahol a lakókörnyékhez kapcsolódó fizikai biztonságérzet magasabb volt, a mintaátlagtól kedvezőbb értékeket mértünk, míg a biztonsághiány erősödése jelentős jóllétpontszám-csökkenést vont maga után. A pesszimisták átlagtól alacsonyabb, az optimisták messze kedvezőbb szubjektív életminőségét mértük a válságot követően is, míg a neutrális attitüd a mintaátlag körüli indexértékkel járt együtt mindkét évben.

Az elemzés további eredménye egyrészt, hogy az egy főre jutó havi nettó háztartási jövedelem és a szubjektív jóllét között mindkét évben gyenge pozitív lineáris kapcsolatot találtunk. Továbbá a gazdasági válság éveiben az egyéni anómia- és elidegenedésérzet elterjedtsége szignifikánsan nőtt a magyar társadalomban. ${ }^{11} \mathrm{~A}$ magasabb anómia és elidegenedés érzet a kétváltozós elemzések alapján alacsonyabb jóllét-realizációs szintet és szubjektív életminőséget vont maga után.

Összefoglalóan elmondható, hogy a demográfiai csoportok szubjektív jólléte nagyobb átrendeződéseket nélkülöző képet mutatott a válságot követően. A 30 év alatti fiatalok magas egyéni életminősége többek között a jóléti társadalmakat jellemző, a globalizációs hatásként értékelt, hosszú távú elköteleződéstől mentes, átlagosan 29 éves korig elhúzódó, szülők mellett kialakított, így kevesebb anyagi problémával járó

${ }^{11}$ A kutatásban kialakított 18 fokú anómia és elidegenedés skála átlagai (2006-ban: 9,39 [N=1 457]; 2012ben: 9,65 [N=1965]) közötti különbség 1 százalékos szinten szignifikáns. (A magasabb skálaértékek magasabb anómia- és elidegenedésérzetet jelentettek.) 
életmintának köszönhető feltehetően (Blossfeld-Mills [2005], Medgyesi-Nagy [2014]). A 70 évtöl idősebbek alacsony indexértékeit a válság éveiben felerősödött bizonytalanságérzet mellett az is magyarázhatja, hogy e korcsoportban magasabb az egyedülállók aránya, mint a 60-69 évesek korcsoportjában. Az egyedülállókhoz viszonyítva - akik átlagos jóllétét a nőtlenek/hajadonok kedvezőbb értékei valamelyest javították - a házasok vagy törvényes élettársi kapcsolatban élők a válság éveiben is átlagostól magasabb szubjektív életminőséget érhettek el, köszönhetően a házasság vagy élettársi kapcsolat kedvező fizikai és pszichés hatásainak (Frey-Stutzer [2003], Hank-Wagner [2013]). A munkaerópiaci jelenlét alapján a válság éveiben elsősorban azok, akik nem dolgoztak, lakossági átlagtól alacsonyabb szubjektív életminőségről adtak számot, melyben a már említett alternatív hipotéziseken túl egyéb magyarázó mechanizmusok is szerepet játszhattak, melyekre további kutatások adhatnak választ.

\section{Az érzelmi jóllét alakulása Magyarországon és az európai országokban}

Az Eurobarometer-kutatás (European Commission [2014]) hét uniós tagállamban készült elemzése megerősítette, hogy a válság éveiben a negatív töltetű érzelmek hangsúlyossá váltak a sérülékeny társadalmi csoportok körében. Az aggodalmak, a stressz, a frusztráció és egyéb negatív érzések vizsgálatára a hazai vonatkozó kutatások egy-egy esetben tértek ki a szubjektív életminőséggel kapcsolatban (Utasi [2011]), ezért e kitekintő nemzetközi elemzés keretében, a kutatáshoz kialakított elméleti koncepcióba ágyazva, az érzelmi jóllét alakulását vizsgáltuk az európai országok körében, 2006 és 2015 közötti időszakban.

A szubjektív életminőség és jóllét tartós és rövid távú érzelmi percepcióit a korábbiakban definiáltuk, azonban hasonló többdimenziós mutató nem volt kialakítható a 2015-ös évben. Ezzel szemben a dieneri teória alapján meghatározott affektív jóllét (Diener [1984]) mérőeszköze mindhárom évben létrehozható volt, a már ismert boldogságérzet és a pozitív-negatív érzelmi balansz skála összetett mutatójaként. ${ }^{12} \mathrm{~A}$ rövid távú érzéseket a 2015-ös év szük változókészlete miatt eltérő mutatókkal operacionalizáltuk, ${ }^{13}$ mint a többdimenziós szubjektív életminőség indikátor esetében.

\footnotetext{
${ }^{12}$ A nemzetközi mintán elkészített komparatív elemzés a szerző 2016. június 14-ei Magyar Tudományos Akadémia Társadalomtudományi Kutatóközpont, European Social Survey mühelykonferencia előadásának részét képezte.

${ }^{13}$ A balansz skála kialakítása a korábbiakhoz hasonlóan történt, a bevont változók a következők: ,Az elmúlt héten milyen gyakran élvezte az életet/volt levert? „....milyen gyakran érzett boldogságot/szomorúságot?” A kérdéseknél a boldogság rövid tartamú állapotáról, tehát örömérzetről van szó, mely átmeneti, időszakos
} 
Az érzelmi jóllét indexet a három időpontban $(2006,2012,2015)$ vagy legalább 2006-ban és egy másik hullámban részt vevő országok esetében fökomponenselemzéssel konstruáltuk, ${ }^{14}$ mely alapján a válságot követő két évben az európai átlaghoz viszonyított eltérések változásait vizsgáltuk. (Lásd a 7. ábrát.)

7. ábra. Az érzelmi jóllét index átlagértékének változása az európai országokban 2006-2015 között (ESS, 2006, 2012, 2015)

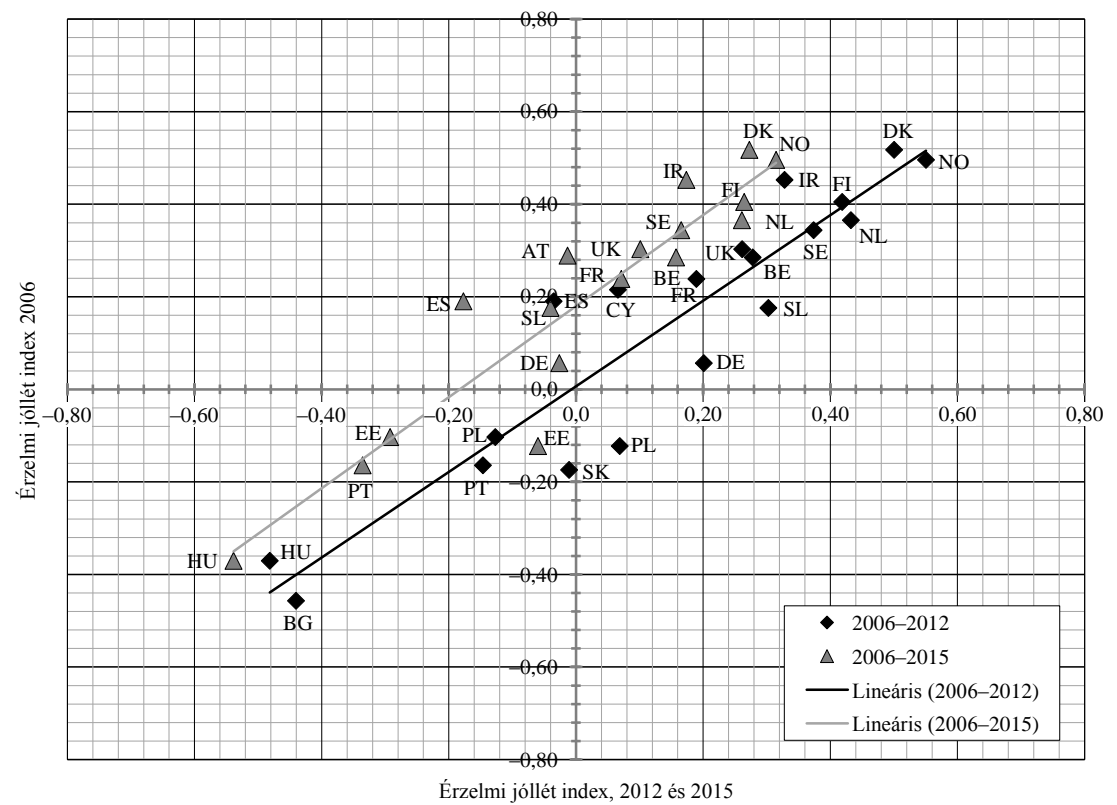

Megjegyzés. Az országnevek rövidítését lásd az ISO 3166 alpha-2 (https://en.wikipedia.org /wiki/ISO_3166-1_alpha-2) alapján.

Az adatok alapján elmondható, hogy az összeurópai átlagtól eltérő legalacsonyabb érzelmi jóllétszintet Bulgáriában és Magyarországon, a legmagasabbat Dániában és Norvégiában találtunk. A két időpont közötti változásokat figyelembe véve a diagram pozitív tartományában elhelyezkedő magas érzelmi jóllétszinttel rendelkező országokat két csoportra bonthatjuk, amelyek javulást, illetve visszaesést mutattak 2012-re. A többségük esetében ez utóbbiról van szó, a 2006-os értékekhez képest

emóció, és nem az élet globális értékelését jelenti a hagyományos értelemben vett boldogság kérdésével szemben. A változók operacionalizálásánál tett szakirodalmi hivatkozás ehhez a fogalmi tisztázáshoz is kapcsolódik.

${ }^{14}$ A korábbiakban leírt módon súlyozott adatokon létrehozott fökomponensek mindhárom évben, minden országban szignifikáns statisztikákat mutattak, 1 darab látens változó jött létre magas sajátértékkel, minden esetben 0,71 fölötti KMO-értékkel és néhány esettől eltekintve (2006-ban Ausztria, Ciprus; 2012-ben Norvégia, Szlovákia) legalább 50,1 százalék magyarázott varianciával. 
valamelyest csökkenő értékeket mértünk a belga, a dán, a francia, az angol, a spanyol, a ciprusi és az ír lakosság körében, míg a finnek, a hollandok, a norvégok és a svédek magasabb érzelmi jóllétpontszámot értek el. Németország és Szlovénia esetében szintén javuló a trend, jóllehet 2006-ban ezek az országok a csoportátlagtól alacsonyabb szinten helyezkedtek el. Az európai átlaghoz viszonyítva 2006-ban alacsonyabb indexpontszámot elérő kelet- és dél-európai országok közül Bulgária, Portugália, Észtország és Magyarország 2012-re változatlanul alacsony, vagy kedvezőtlenebb érzelmi jóllétszintet mutatott, javulást ebben a csoportban Szlovákia és Lengyelország esetében láttunk. A 2015-ös adatokat is bevonva az elemzésbe, a válság időszakát követően is az érzelmi jóllétszint átlagos csökkenéséről beszélhetünk az európai lakosság körében. Látható, hogy a korábbi pozíciót az északi országoknak sem sikerült megtartaniuk, amit a két időszak átlagos trendjét kifejező egyenesek távolsága is jelez. A magyarok alacsony érzelmi jólléte a kelet- és dél-európai országok csoportján belül itt egyedül Bulgáriát előzi meg, messze elmaradva a középmezőnytöl, de elsősorban az északi országoktól.

\section{6. Összefoglalás}

Magyarországon a gazdasági válság időszakát vizsgálva a szubjektív jóllét egyenlőtlen megoszlását tapasztaltuk. Az eredmények alapján elsősorban a sérülékeny társadalmi csoportok szubjektív életminőségének átlagostól jóval kedvezőtlenebb helyzetéről számolhattunk be a kilábalás időszakában, melyet az ország gazdasági állapota, a válságkezelés elhúzódása, a háztartások romló jövedelmi körülményei mellett természetesen egyéb tényezők is befolyásolhattak. A szubjektív életminőség és jóllét mértékét meghatározó javak közül a „loving” dimenzió eloszlása volt a magyar társadalomban a legkevésbé egyenlötlen, ami a korábbi kutatásokkal (Utasi [2008]) összhangban jelzi, hogy az egyéni jóllét mértékét a támogató családi és baráti kapcsolatok voltak képesek leginkább, vagy mondhatni egyedül javítani, illetve fenntartani a kilábalás éveiben. A gazdasági válság negatív járulékos hatásaként az európaiak érzelmi jóllétének kedvezőtlen trendjét több országban alacsonyabb boldogságérzet és érzelmi egyenleg együttes jelenléteként mértük a recesszió éveit követően is. Jelen leíró elemzésen túl, azzal kapcsolatosan, hogy egyes társadalmi nagycsoportok szubjektív életminőségbeli különbségei milyen irányú és mértékü eltérést mutattak a krízist követően a később megjelenő, összevont keresztmetszeti adatokon elkészített többváltozós elemzés ad számot. 


\section{Irodalom}

AllardT, E. [1973]: About Dimensions of Welfare - An Exploratory Analysis of a Comparative Scandinavian Survey. Research Reports. No. 1. Research Group for Comparative Sociology University of Helsinki. Helsinki. http://worlddatabaseofhappiness.eur.nl/hap_bib/ freetexts/allardt_e_1973.pdf

AllardT, E. [1993]: Having, loving, being: an alternative to the Swedish model of welfare research. In: Nussbaum, M. - Sen, A. (eds.): The Quality of Life. Clarendon Press. Oxford pp. 88-94. http://dx.doi.org/10.1093/0198287976.003.0008

ANDORKA R. [1996]: Deviáns viselkedések Magyarországon. Általános értelmezési keret az elidegenedés és az anómia fogalmak segítségével. In: Andorka R. (szerk.): Merre tart a magyar társadalom. Antológia. Lakitelek. 32-78. old.

ANDORKA R. - SPÉDER Zs. [1994]: Szegénység a 90-es évek elején. In: Andorka R. - Kolosi T. Vukovich Gy. (szerk.): Társadalmi Riport 1994. TÁRKI. Budapest. 74-106. old.

ANDORKA R. - SPÉDER Zs. [1996]: A szegénység Magyarországon, 1992-1995. Esély. 8. évf. 4. sz. 25-52. old. http://esely.org/kiadvanyok/1996_4/aszegenyseg_magyarorszagon.pdf

ANDREws, F. M. - WitheY, S. B. [1974]: Developing measures of perceived life quality: results from several national surveys. Social Indicators Research. Vol. 1. Issue 1. pp. 1-26. http://dx.doi.org/10.1007/BF00286419

Bernát A. - Kopasz M. - Simonovits B - Kozma Á. - Verdes T. - BugarszKi Zs. [2016]: Fogyatékossággal élö emberek életminősége és ellátási költségei különbözö lakhatási formákban. TÁRKI. Budapest. http://fszk.hu/wp-content/uploads/2016/04/TARKI_FSZK_PROGRESS _zarotanulmany.pdf

Berger-Scmitt, R. - Noll, H.-H. [2000]: Conceptual Framework and Structure of a European System of Social Indicators. EuReporting Working Paper. No. 9. Centre for Survey Research and Methodology (ZUMA). Mannheim.

Blossfeld, H.-P. - Mills, M. [2005]: Globalization, uncertainty and the early life course. A theoretical framework. In: Blossfeld, H. P. - Klijzing, E. - Mills, M. - Kurz, K. (eds.): Globalization, Uncertainty and Youth in Society. Routledge Advances in Sociology. London, New York. pp. 1-24.

DelHeY, J. - BÖHNKE, P. - HABICH, R. - ZAPF, W. [2002]: Quality of life in a European perspective: the EURO-MODULE as a new instrument for comparative welfare research. Social Indicators Research. Vol. 58. No. 1-3. pp. 163-176.

Diener, E. [1984]: Subjective well-being. Psychological Bulletin. Vol. 95. No. 3. pp. 542-575. http://dx.doi.org/10.1037/0033-2909.95.3.542

DIENER, E. [1994]: Assessing subjective well-being: progress and opportunities. Social Indicators Research. Vol. 31. No. 2. pp. 103-157. http://dx.doi.org/10.1007/BF01207052

Diener, E. - EunKook, M. S. - Richard, E. L. - Heidi, L. S. [1999]: Subjective well-being: three decades of progress. Psychological Bulletin. Vol. 125. No. 2. pp. 276-302. http://dx.doi.org/10.1037/0033-2909.125.2.276

Diener, E. - LuCAS, R. E. [1999]: Personality and subjective well-being. In: Kahneman, D. Diener, E. - Schwarz, N. (eds.): Well-being - The Foundations of Hedonic Psychology, Russell-Sage Foundation. New York. pp. 213-229. 
DIENER, E. [2006]: Guidelines for national indicators of subjective well-being and ill-being. Journal of Happiness Studies. Vol. 7. No. 4. pp. 397-404. http://dx.doi.org/10.1007/s10902-0069000-y

Diener, E. - Wirtz, D. - Tov, W. - Kim-Pietro, C. - Choi, D. - Oisho, S. - Biswas-Diener, R. [2010]: New well-being measures: short scales to asses flourishing and positive and negative feelings. Social Indicators Research. Vol. 97. No. 2. pp. 143-156. http://dx.doi.org/10.1007/s11205-009-9493-y

DuRKhEIM É. [1982]: Az öngyilkosság. Közgazdasági és Jogi Könyvkiadó. Budapest.

Dow, G. K. - JusteR, F. T. [1985]: Goods, time, and well-being: the joint dependence problem. In: Juster, F. T. - Stafford, F. P. (eds.): Time, Goods, and Well-Being. University of Michigan Press. Ann Arbor. pp. 397-413.

EleKes Zs. - PAKSI B. [2000]: Anómia, lelki problémák, elégedettség - az ezredév végén. In: Spéder Zs. (szerk.): EURÓPA - Kutatási Gyorsjelentés. KSH Népességtudományi Kutatóintézet. Budapest. 55-68. old.

EuRopeAn COMMISSION [2014]: Coping with the Crisis. Aggregate Report. Eurobarometer Qualitative Study. Luxembourg. http://ec.europa.eu/commfrontoffice/publicopinion/archives/ quali/q1_6342_crisis_en.pdf

Frey, B. S. - Stutzer, A. [2003]: Does Marriage People Happy, Or Do Happy People Get Married. Institute for Empirical Research in Economics. Working Paper. No. 143. University of Zurich, Zurich. http://www.iew.uzh.ch/wp/iewwp143.pdf

Garhammer, M. [2002]: Pace of life and enjoyment of life. Journal of Happiness Studies. Vol. 3. No. 3. pp. 217-256.

GÁbos A. - BRANyiCZKi R. - LANGE B. - Tóth I. Gy. [2014]: Aktív korúak foglalkoztatottsága és szegénysége az Európai Unióban és Magyarországon: válság előtt, alatt és után. In: Kolosi T. Tóth I. Gy. (szerk.): Társadalmi Riport 2014. TÁRKI. Budapest. 179-203. old.

GÁBos A. - TÁtrai A. - B. Kis A. - Szivós P. [2016]: Anyagi depriváció Magyarországon, 2009-2015. In: Kolosi T. - Tóth I. Gy. (szerk.): Társadalmi Riport 2016. TÁRKI. Budapest. 130-150. old.

HAJDÚ G. - HAJDÚ T. [2011]: Elégedettség és relatív jövedelem: a referenciacsoport összetételének hatása az információs és státuszhatás erősségére. Szociológiai Szemle. 21. évf. 3. sz. 83-106. old.

HANKISS, E. [1980]: Structural variables in cross-cultural research on the quality of life. In: Szalai, A. - Andrews, F. M. (eds.): The Quality of Life. Comparative Studies. Sage Studies in International Sociology. No. 20. pp. 41-56.

HANK, K. - Wagner, M. [2013]: Parenthood, marital status, and well-being in later life: evidence from SHARE. Social Indicators Research. Vol. 114. No. 2. pp. 639-653. http://dx.doi.org/10.1007/s11205-012-0166-x

HARCSA, I. - SPÉDER, Zs. [1999]: Social Reporting and Social Indicators Movement in Hungary Before and After the Transformation. EuReporting Working Paper. No. 4. Hungarian Central Statistical Office, Budapest University of Econmomic Sciences. Budapest.

HEADEY, B. [2010]: The set-point theory of well being has serious flaws: on the eve of a scientific revolution? Social Indicators Research. Vol. 97. No. 1. pp. 7-21. http://dx.doi.org/10.1007/s11205-009-9559-x

Headey, B. - Muffels, R. - Wagner, G. G. [2014]: National panel studies show substantial minorities recording long-term change in life satisfaction: implications for set-point theory. In: 
Sheldon, K. M. - Lucas, R. E. (eds.): Stability of Happiness - Theories and Evidence on Whether Happiness Can Change. Elsevier Inc. Amsterdam. pp. 101-126. http://dx.doi.org/10.1016/B978-0-12-411478-4.00006-0

Headey, B. - Wearing, A. [1989]: Personality, life events, and subjective well-being: toward a dynamic equilibrium model. Journal of Personality and Social Psychology. Vol. 57. No. 4. pp. 731-739. http://dx.doi.org/10.1037/0022-3514.57.4.731

IvONY É. [2017]: A válság hatása a szubjektív életminöségre és meghatározó tényezőire Magyarországon. Doktori értekezéstervezet. Budapesti Corvinus Egyetem. Budapest.

Kim-Prieto, C. - Diener, E. - TAmir, M. - Scollon, C. - Diener, M. [2005]: Integrating the diverse definitions of happiness: a time-sequential framework of subjective well-being. Journal of Happiness Studies. Vol. 6. No. 3. pp. 261-300. http://dx.doi.org/10.1007/s10902-005-7226-8

LANE, R. E. [1996]: Quality of life and quality of persons: a new role for government? In: Offer, A. (ed.): In Pursuit of the Quality of Life. Oxford University Press Inc. New York. pp. 256-293.

LENGYEL Gy. - JANKY B. [2002]: A szubjektív jólét társadalmi feltételei. In: Lengyel Gy. (szerk.): Indikátorok és elemzések. Mühelytanulmányok a társadalmi jelzöszámok témaköréböl. Budapesti Közgazdasági és Államigazgatási Egyetem. Budapest. 105-126. old.

MEDGYESI M. - NAGY I. [2014]: Fiatalok életkörülményei Magyarországon és az EU országaiban 2007 és 2012 között. Kolosi T. - Tóth I. Gy. (szerk.): Társadalmi Riport 2014. TÁRKI. Budapest. 303-323. old.

Michalos, A. C. - Zumbo, B. D. [2002]: Healthy days, health satisfaction and satisfaction with the overall quality of life. Social Indicators Research. Vol. 59. No. 3. pp. 321-338.

NoLL, H.-H. [2002]: Social indicators and quality of life research: background, achievements and current trends. In: Genov, N. (ed): Advances in Sociological Knowledge - Over Half a Century. Springer. Weisbaden. pp. 151-181. https://www.gesis.org/fileadmin/upload/institut/ wiss_arbeitsbereiche/soz_indikatoren/Publikationen/isscnoll.pdf

NoLL, H.-H. [2011]: The Stiglitz-Sen-Fitoussi-report: old wine in new skins? Views from a social indicators perspective. Social Indicators Research. Vol. 102. No. 1. pp. 111-116. http://dx.doi.org/10.1007/s11205-010-9738-9

SÁGI M. [2000]: Az anyagi helyzettel való elégedetlenség és a vonatkoztatási csoportok. In: Kolosi T. - Tóth I. Gy. - Vukovich Gy. (szerk.): Társadalmi Riport 2000. TÁRKI. Budapest. 260-297. old.

SCHARLE Á. [2016]: Mennyit nőtt a foglalkoztatás 2008 óta Magyarországon? In: Kolosi T. - Tóth I. Gy. (szerk.): Társadalmi Riport 2016. TÁRKI. Budapest. 54-72. old.

SCHULZ, W. [1995]: Multiple-discrepancies theory versus resource theory. Social Indicators Research. Vol. 34. No. 1. pp. 153-169. http://dx.doi.org/10.1007/BF01078971

SEN, A. [1993]: Capability and well-being. In: Nussbaum, M. - Sen, A. (eds.): The Quality of Life. Clarendon Press. Oxford. pp. 30-53. http://dx.doi.org/10.1093/0198287976.003.0003

SPÉDER Zs. - PAKSI B. - EleKES Zs. [1998]: Anómia és elégedettség a 90-es évek elején. In: Kolosi T. - Tóth I. Gy. - Vukovich Gy. (szerk.): Társadalmi Riport 1998. TÁRKI. Budapest. 490-513. old.

SPÉDER Zs. - KAPITÁNY B. [2002]: A magyar lakosság elégedettségének meghatározó tényezői nemzetközi összehasonlításban. In: Kolosi T. - Tóth I. Gy. - Vukovich Gy. (szerk.): Társadalmi Riport 2002. TÁRKI. Budapest. 162-172. old.

SzABÓ L. [2003]: A boldogság relatív - Fogyatékosság és szubjektív életminőség. Szociológiai Szemle. 13. évf. 3. sz. 86-105. old. 
SzIVós P. - TóTH I. Gy. (szerk.) [2013]: Egyenlötlenség és polarizálódás a magyar társadalomban. TÁRKI Monitor Jelentések 2012. TÁRKI. Budapest.

SzIvós P. - TóTH I. Gy. (szerk.) [2015]: Jól nézünk ki (...?!) Háztartások helyzete a válság után. TÁRKI Monitor Jelentések 2014. TÁRKI. Budapest.

UtASI Á. [2002]: A bizalom hálója. Mikrotársadalmi kapcsolatok, szolidaritás. Új Mandátum Kiadó. Budapest.

UTASI Á. [2008]: Éltetö kapcsolatok. A kapcsolatok hatása a szubjektív életminöségre. Új Mandátum Kiadó. Budapest.

UTASI Á. [2011]: Szubjektív feszültség és munkastressz a házasok életében. Összehasonlítás Európa 24 országában. In: Nagy I. - Pongrácz T. (szerk.): Szerepváltozások: Jelentés a nök és férfiak helyzetéröl 2011. TÁRKI. Budapest. 243-264. old.

Van Praag, B. M. S. - FriJters, P. - Ferreri-Carbonell, A. [2001]: The Anatomy of Subjective Well-Being. Discussion Papers. Nr. 02-022/3. Timbergen Institute. Amsterdam. http//:ideas.repec.org./p/dgr/uvatin/20020022.html

VeEnhoven, R. [2000]: The four qualities of life. Ordering concepts and measures of the good life. Journal of Happiness Studies. Vol. 1. No. 1. pp. 1-39.

VeEnhoven, R. [2016]: Happiness in Hungary (HU). World Database of Happiness. Erasmus University Rotterdam. Rotterdam. http://worlddatabaseofhappiness.eur.nl

Vogel, J. [1997]: The future direction of social indicator research. Social Indicators Research. Vol. 42. No. 2. pp. 103-116.

Wrosch, C. - ScheIER, M. F. [2003]: Personality and quality of life: the importance of optimism and goal adjustment. Quality of Life Research. Vol. 12. No. 1. pp. 59-72.

ZAPF, W. [1980]: The SPES social indicators system in comparative perspective. In: Szalai, A. - Andrews, F. M. (eds.): The Quality of Life. Comparative Studies. No. 20. Sage. London. pp. 249-269.

ZAPF, W. [2000]: Social reporting in the 1970s and in the 1990s. Social Indicators Research. Vol. 51. No. 1.pp. 1-15.

\section{Summary}

The present study focuses on the changes in the subjective quality of life of Hungarians during the economic crisis, concentrating on different socio-demographic sections. By using the multidimensional quality of life index, this descriptive analysis compares two periods: before and after the crisis. The data used come from the $3^{\text {rd }}(2006)$ and $6^{\text {th }}(2012)$ waves of the European Social Survey, while the international analysis of the study is supplemented with data for the year 2015 . The results show that the young, as well as those who are married, live in partnerships, and generally have more re-sources were able to realize higher than average subjective quality of life even during the years of the crisis. The lower than average well-being of the divorced or widowed did not change remarkably in the examined period. Nevertheless, the individual well-being of the elderly (age 70+), the unskilled, the unemployed, the chronically ill and of those who gave the worst subjective health-rating, was far the lowest in 2012. At the same time, the spread of anomie accelerated and the feeling of alienation increased among Hungarian citizens during this period. The analysis of the international data shows an average downward trend of the affective well-being among European and Hungarian citizens. 